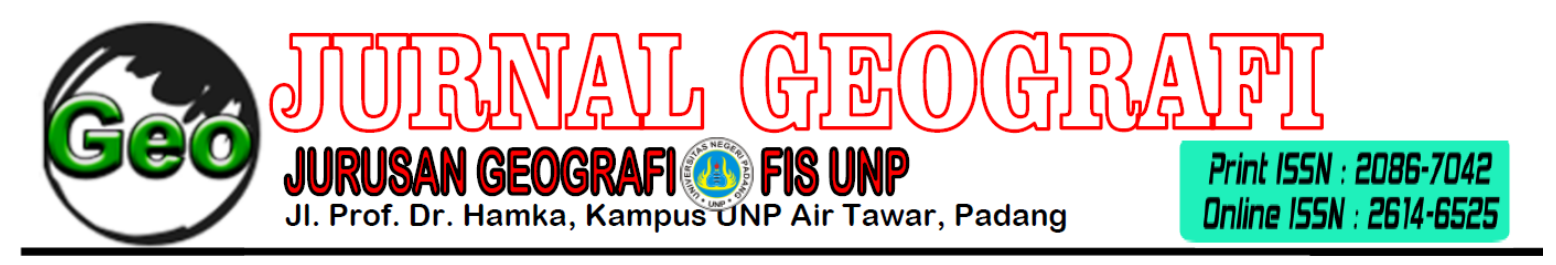

\title{
IDENTIFIKASI PERUBAHAN PENGGUNAAN LAHAN DI SEMPADAN BATANG ARAU TAHUN 2005-2015 KOTA PADANG
}

\author{
Nurkholilah $^{1}$, Helfia Edial ${ }^{2}$, Yudi Antomi ${ }^{2}$ \\ ${ }^{1,2}$ Jurusan Geografi, Program Studi Geografi, \\ Fakultas Ilmu Sosial, Universitas Negeri Padang \\ Email: nurkholilah672@gmail.com
}

\begin{abstract}
ABSTRAK
Penelitian ini bertujuan: 1) Mengetahui penggunaan lahan di sempadan Batang Arau tahun 20052015 2) Mengetahui perubahan penggunaan lahan di sempadan Batang Arau tahun 20052015.Penelitian ini merupakan penelitian kuantitatif dengan menggunakan pendekatan deskriptif. Data yang digunakan Citra Quickbird Tahun 2005 dan citra SPOT 6 Tahun 2015. Metode yang digunakan dalam penelitian ini adalah overlay peta penggunaan lahan yang diperoleh dari analisis citra digital dengan bantuan software ArcGis 10.1. Dalam penelitian ini diperoleh hasil, 1) Penggunaan lahan di sempadan Batang Arau tahun 2005 didominasi oleh pemukiman mencakup 236,639 Ha, kebun campuran mencakup 100,409 Ha, sawah mencakup 91,946 Ha dan hutan yaitu 15,266 Ha. Sedangkan penggunaan lahan tahun 2015 yang dominan masih sama dengan penggunaan lahan tahun 2005 yaitu pemukiman mencakup 250, $295 \mathrm{Ha}$, luas lahan kebun campuran bertambah yaitu 130,096 Ha, luas lahan sawah berkurang sekitar 43,48 Ha dan luas lahan hutan bertambah yaitu sekitar 20,428 Ha. 2) Perubahan penggunaan lahan yang mengalami pengurangan adalah sawah dengan luas $-14,412 \mathrm{Ha}$, sedangkan penggunaan lahan yang mengalami perluasan adalah pemukiman dengan luas $22,986 \mathrm{Ha}$, hutan dengan luas 10,104 Ha, kebun campuran dengan luas 17,072Ha.
\end{abstract}

Kata kunci: Penggunaan Lahan, Perubahan, Garis Sempadan

\section{ABSTRACT}

This study aims to: 1) Know the land use in Batang Arau border in 2005-2015 2) Know the changes in land use in Batang Arau border in 2005-2015. This research is a quantitative research using descriptive approach. Date used Quickbird Image in 2005 and Image SPOT 62015. Analysis using overlay method of land use map with the help of ArcGis 10.1 software. In this research, 1) Land use in river Arau Border in 2005 is dominated by settlement covering 236,639 $\mathrm{Ha}$, mixed plantation covers 100,409 $\mathrm{Ha}$, rice field covers 91,946 $\mathrm{Ha}$ and forest is 15,266 Ha. While the dominant land use in 2015 is still the same as the land use in 2005, the settlement covers 250,295 ha, the area of mixed plantation land is increased by 130,096 Ha with the width of rice field decreasing about 43,48 Ha and the forest land area is increased about 20,428 Ha. 2) The change of land use are reduce with widespread rice fields $-14,412 \mathrm{Ha}$, while the expansion of land use is a settlement with an area of 22,986 $\mathrm{Ha}$, a forestwith an area of 10,104 $\mathrm{Ha}$, a mixed garden with an area of 17,072 $\mathrm{Ha}$.

Keywords: Land Use, Change, Border Line 


\section{PENDAHULUAN}

Kota Padang sebagai ibu kota Provinsi Sumatera Barat merupakan salah satu pusat kegiatan ekonomi dan pendidikan di Sumatera Barat. Peran ini sangat mendukung terjadinya dinamika kependudukan di kota Padang. Kota Padang memiliki jumlah penduduk terbesar diantara Kota dan Kabupaten seSumatra Barat. Ini dibuktikan dengan pertambahan penduduk setiap tahunnya, tercatat jumlah penduduk Kota Padang pada tahun 2001 adalah 720.753 jiwa, jumlah penduduk pada tahun 2009 sudah mencapai 875.750 jiwa dengan laju pertumbuhan penduduk sebesar 1,09\% (Padang Dalam Angka, 2012) Peningkatan jumlah penduduk telah menyebabkan meningkatnya kebutuhan akan tempat tinggal, permintaan yang tinggi tidak sebanding dengan ketersediaan lahan yang ada sehingga terjadi pemanfaatan lahan pada area terlarang. Masyarakat telah melakukan pemanfaatan lahan, di kawasan sempadan sungai yang menurut peraturan perundang- undangan yang berlaku terlarang untuk didirikan bangunan baik untuk industri atau pemukiman (Peraturan Menteri Pekerjaan Umum No. 28 Tahun 2015).

Sungai adalah tempat-tempat dan wadah-wadah serta jaringan pengaliran air mulai dari mata air sampai muara dengan dibatasi kanan dan kirinya sepanjang pengalirannya oleh sempadan (PP RI No. 35 Tahun 1991 tentang Sungai). Sungai dan daerah sempadan sungai adalah sumberdaya milik umum, sehingga tidak dapat dijadikan hak milik perseorangan dan seluruh masyarakat harus memiliki kesempatan yang sama untuk dapat memanfaatkannya. Fungsi sempadan sungai bagi perlindungan ekosistem sungai dan daratan (Peraturan Menteri Pekerjaan Umum Nomor 63/PRT/1963 tentang garis sempadan sungai).

DAS Batang Arau merupakan salah satu DAS yang terdapat di Kota Padang. Penggunaan Lahan di daerah hulu DAS ini berupa hutan serta terdapat juga industri dan pertambangan pada kawasan hutan tersebut, sedangkan pada bagian tengah dan hilir digunakan untuk pertanian, perkebunan campuran dan pemukiman. Pertumbuhan penduduk di DAS Batang Arau yang semakin pesat serta bertambahnya tuntutan kebutuhan masyarakat akan lahan, seringkali mengakibatkan benturan kepentingan atas penggunaan lahan serta terjadinya ketidaksesuaian antara penggunaan lahan dengan rencana peruntukannya

Pengurangan luas penggunaan lahan terbesar terjadi pada periode 20002009, terutama setelah lima tahun pertama bergulirnya reformasi. Berkurangnya luas penggunaan lahan terjadi karena adanya pembukaan lahanlahan hutan untuk ladang (pertanian lahan kering) berpindah dan maraknya penebangan liar. Pembukaan lahan untuk pertanian lahan kering terjadi karena adanya alih fungsi lahan pertanian menjadi pemukiman sehingga kemudian petani membuka hutan untuk pertanian (Bapedalda 2010).

$$
\text { Dalam } 20 \text { tahun terakhir }
$$

Kecamatan Lubuk Begalung (DAS Batang Arau). Pertambahan jumlah penduduknya mencapai antara 2 sampai 3 kali lipat dalam 20 tahun terakhir, sehingga penduduk mulai membuka 
lahan hutan untuk pertanian, karena sebagian lahan pertanian produktif telah dijadikan pemukiman, perkantoran dan lahan usaha, industri dan jasa (Bapedalda 2010).

Oleh sebab itu penelitian ini bertujuan untuk mengetahui bagaimana penggunaan lahan di sempadan Batang Arau tahun 2005-2015 dan perubahan penggunaan lahan di sempadan Batang Arau tahun 2005-2015.

Menurut UU No 41 Tahun 1999 tentang kehutanan menjelaskan bahwa, lahan merupakan suatu hamparan ekosistem daratan yang diperuntukkan untuk usaha dibidang kehutanan, perkebunan, pertanian, transmigrasi, pertambangan, pariwisata dan ladang serta kebun bagi masyarakat.

Menurut Widyaningsih (2008) Berbagai tipe penggunaan lahan dijumpai di permukaan bumi, masing-masing tipe mempunyai kekhususan tersendiri. Tipe penggunaan lahan secara umum meliputi pemukiman, kawasan budidaya pertanian, padang penggembalaan, kawasan rekreasi dan lainnya.

Badan Pertanahan Nasional dalam Pratama (2010) mengelompokkan jenis penggunaan lahan sebagai berikut: (1)pemukiman berupa kombinasi antara jalan, bangunan, tegalan/pekarangan, dan bangunan itu sendiri (kampung dan emplasemen); (2) kebun meliputi kebun campuran dan kebun sayuran merupakan daerah yang ditumbuhi vegetasi tahunan satu jenis maupun campuran, baik dengan pola acak maupun teratur sebagai pembatas tegalan; (3) tegalan merupakan daerah yang ditanami umumnya tanaman semusim, namun pada sebagian lahan tak ditanami dimana vegetasi yang umum dijumpai adalah padi gogo, singkong, jagung, kentang, kedelai dan kacang tanah; (4) sawah merupakan daerah pertanian yang ditanami padi sebagai tanaman utama dengan rotasi tertentu yang biasanya diairi sejak penanaman hingga beberapa hari sebelum panen; (5) hutan merupakan wilayah yang ditutupi oleh vegetasi pepohonan, baik alami maupun dikelola manusia dengan tajuk yang rimbun, besar serta lebat; (6) lahan terbuka, merupakan daerah yang tidak terdapat vegetasi maupun penggunaan lain akibat aktivitas manusia; (7) semak belukar adalah daerah yang ditutupi oleh pohon baik alami maupun yang dikelola dengan tajuk yang relatif kurang rimbun.

Perubahan penggunaan lahan adalah bertambahnya suatu penggunaan lahan dari satu sisi penggunaan ke penggunaan yang lainnya diikuti dengan berkurangnya tipe penggunaan lahan yang lain dari suatu waktu ke waktu berikutnya, atau berubahnya fungsi suatu lahan pada kurun waktu yang berbeda (Martin, 1993 dalam Wahyunto, 2001).

Perubahan penggunaan lahan dalam pelaksanaan pembangunan tidak dapat dihindari. Perubahan tersebut terjadi karena dua hal, pertama adanya keperluan untuk memenuhi kebutuhan penduduk yang makin meningkat jumlahnya dan kedua berkaitan dengan meningkatnya tuntutan akan akan mutu kehidupan yang lebih baik. Para ahli berpendapat bahwa perubahan penggunaan lahan lebih disebabkan oleh adanya kebutuhan dan keinginan manusia.

Secara umum struktur yang berkaitan dengan perubahan penggunaan lahan dapat dibagi menjadi tiga yaitu (1) 
struktur permintaan atau kebutuhan lahan, (2) struktur penawaran atau ketersediaan lahan dan (3) struktur penguasaan teknologi yang berdampak pada produktivitas sumber daya lahan Saefulhakim (1999) dalam Yani (2009).

Dalam perkembangannya perubahan lahan tersebut akan terdistribusi pada tempat-tempat tertentu yang mempunyai potensi yang baik. Selain distribusi perubahan penggunaan, lahan akan mempunyai pola-pola perubahan penggunaan lahan. Menurut Bintarto (1977) dalam Yani (2009) pola distribusi perubahan penggunaan lahan pada dasarnya dikelompokkan menjadi:

a. Pola memanjang mengikuti jalan

b. Pola memanjang mengikuti sungai

c. Pola tersebar

d. Pola memanjang mengikuti garis pantai

e. Pola memanjang mengikuti garis pantai dan rel kereta api.

Sutanto (1992) menjelaskan Citra Quickbird beresolusi spasial paling tinggi dibanding citra satelit komersial lainnya. Posisi orbitnya rendah, 400-600 km di atas Bumi. Data yang diperoleh dari citra Quickbird dilakukan interpretasi dengan menggunakan kunci interpretasi, seperti; rona dan warna, ukuran, bentuk, tinggi, bayangan, pola, tekstur, asosiasi. Oleh karena itu, citra Quickbird sangat cocok untuk menganalisis perubahan penggunaan lahan. Dengan menggunakan Citra Quickbird maka perubahan penggunaan lahan dapat dianalisis dengan mudah karena batas-batas pada obyek akan tampak lebih jelas, misalnya sebuah lokasi permukiman dapat diidentifikasi per individu bangunan, sebuah jaringan jalan dapat didentifikasi sebagai poligon dua sisi, dan lain sebagainya.

\section{METODE PENELITIAN}

Metode yang dipakai dalam penelitian ini adalah metode deskriptif secara kuantitatif. Deskriptif kuantitatif merupakan salah satu bentuk dari penelitian yang bertujuan untuk menerangkan, menggambarkan gejalagejala, fakta-fakta dan sifat populasi pada daerah penelitian dengan maksud memberikan gambaran mengenai keadaan yang ada pada daerah penelitian. (Arikunto, 2010).

Penelitian ini dilakukan di Sempadan Batang Arau Kota Padang. Dalam pelaksanaannya penelitian ini dilakukan selama satu bulan yaitu pada bulan januari 2017

Teknik pengumpulan data dilakukan untuk memperoleh data-data sekunder yang berbentuk dokumen didapatkan dari instansi-instansi terkait yaitu berkaitan dengan citra quickbird tahun 2005, citra quickbird tahun 2015 dan peta DAS Batang Arau dan data primer yang didapatkan melalui observasi atau pengamatan langsung dari lapangan untuk melihat kondisi penggunaan lahan dilapangan.

Teknik analisis data yang digunakan yaitu analisis buffer yang untuk membatasi penggunaan lahan di sepanjang sempadan Batang Arau sejauh $100 \mathrm{~m}$ di kiri kanan sungai.

Selanjutnya menggunakan teknik overlay dengan menampalkan suatu peta digital pada peta digital yang lain beserta atribut-atributnya dan menghasilkan peta gabungan keduanya yang memiliki informasi atribut dari kedua peta tersebut. 
Hasil tumpang susun antara hasil digitasi aliran sungai dan penggunaan lahan citra quickbird tahun 2005 dan citra SPOT 6 tahun 2015 dari Arcgis.

\section{HASIL DAN PEMBAHASAN}

\section{Penggunaan lahan di sempadan} Batang Arau tahun 2005-2015

Penggunaan lahan berkaitan dengan aktivitas manusia yang secara langsung berhubungan dengan lahan, dimana terjadi penggunaan dan pemanfaatan lahan dan sumber daya yang ada serta menyebabkan dampak pada lahan. Contoh penggunaan lahan yaitu tanaman kehutanan, pemukiman, lapangan olah raga, rumah sakit, rumah makan, kuburan dan lain sebagainya.

Berdasarkan hasil interpretasi citra maka diperoleh penggunaan lahan di sempadan Batang Arau tahun 2005 dapat dilihat pada tabel berikut di bawah ini:

Tabel 1. Luas Penggunaan Lahan Tahun 2005

\begin{tabular}{llll}
\hline No. & $\begin{array}{l}\text { Penggunaan } \\
\text { Lahan }\end{array}$ & Luas (Ha) & $\begin{array}{l}\text { Persentase } \\
(\%)\end{array}$ \\
\hline 1 & Hutan & 15,266 & 3,44 \\
\hline 2 & $\begin{array}{l}\text { Kebun } \\
\text { Campuran }\end{array}$ & 100,409 & 22,60 \\
\hline 3 & Permukiman & 236,639 & 53,26 \\
\hline 4 & Sawah & 91,946 & 20,70 \\
\hline & Total & $\mathbf{4 4 4 , 2 6}$ & $\mathbf{1 0 0}$ \\
\hline
\end{tabular}

Sumber: Analisis Citra Quicbird Tahun 2005

Berdasarkan tabel di atas, dapat dilihat bahwa penggunaan lahan tahun 2005 adalah didominasi oleh pemukiman mencakup 236,639 Ha, kebun campuran mencakup 100,409 Ha dengan persentase $22,60 \%$, sawah mencakup 91,946 Ha dengan persentase $20,70 \%$ dan hutan yaitu 15,266 Ha dengan persentase $3,44 \%$.

Sebaran penggunaan lahan di sempadan Batang Arau tahun 2005 hasil analisis penggunaan lahan di sajikan lebih jelasnya pada peta penggunaan lahan di sempadan Batang Arau Tahun 2005 yang dapat di lihat padaberikut ini:

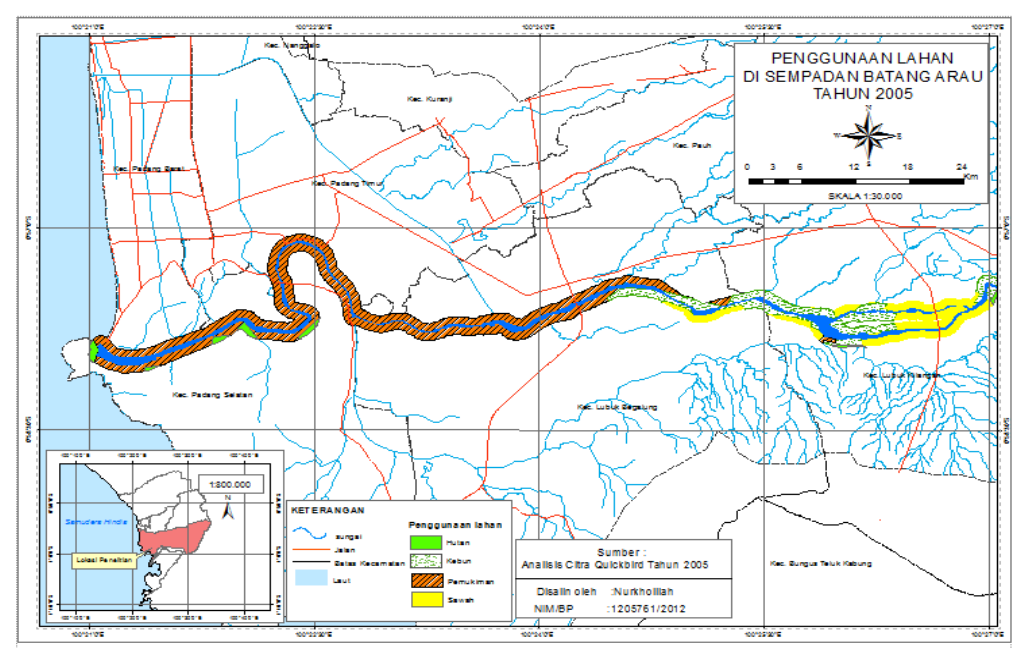

Gambar 1. Peta Penggunaan Lahan di Sempadan Batang Arau Tahun 2005

Berdasarkan hasil interpretasi citra SPOT 6 maka diperoleh penggunaan lahan di sempadan Batang Arau tahun
2015 dapat dilihat pada tabel berikut dibawah ini: 
Tabel 2. Luas Penggunaan Lahan Tahun 2015

\begin{tabular}{llll}
\hline No. & $\begin{array}{l}\text { Penggunaan } \\
\text { Lahan }\end{array}$ & Luas (Ha) & $\begin{array}{l}\text { Persentase } \\
(\%)\end{array}$ \\
\hline 1 & Hutan & 20,428 & 4,51 \\
\hline 2 & $\begin{array}{l}\text { Kebun } \\
\text { Campuran }\end{array}$ & 130,096 & 26,09 \\
\hline 3 & Permukiman & 250,295 & 54,94 \\
\hline 4 & Sawah & 43,48 & 14,46 \\
\hline & Total & $\mathbf{4 4 4 , 2 6}$ & $\mathbf{1 0 0}$ \\
\hline
\end{tabular}

Sumber: Analisis Citra SPOT 6 Tahun 2015

Berdasarkan tabel diatas penggunaan lahan tahun 2015 yang dominan masih sama dengan penggunaan lahan tahun 2005 yaitu pemukiman mencakup 250,295 Ha dengan persentase $54,94 \%$. Luas lahan kebun campuran berkurang yaitu 130,096 Ha dengan persentase $26,09 \%$, luas lahan sawah berkurang sekitar 43,48 Ha dengan persentase $14,46 \%$ dan luas lahan hutan bertambah yaitu sekitar 20,428 Ha dengan persentase $4,51 \%$.

Sebaran penggunaan lahan di sempadan Batang Arau tahun 2015 hasil analisis penggunaan lahan di sajikan lebih jelasnya pada peta penggunaan lahan di sempadan Batang Arau tahun 2015 yang dapat dilihat pada gambar 2 berikut ini:

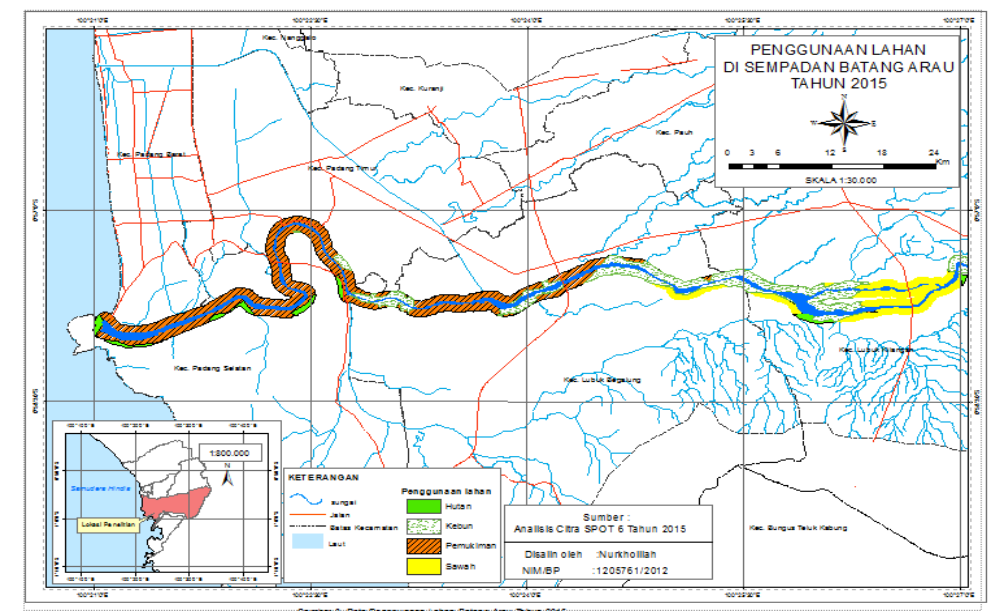

Gambar 2. Peta Penggunaan Lahan di Sempadan Batang Arau Tahun 2015

2. Perubahan penggunaan lahan di sempadan Batang Arau tahun 20052015

Perubahan penggunaan lahan merupakan berubahnya bentuk penggunaan lahan yang satu menjadi bentuk penggunaan yang lain. Bentuk perubahannya dapat dilihat melalui analisis hasil overlay peta penggunaan lahan tahun 2005 dan peta penggunaan lahan tahun 2015.
Hasil analisis overlay penggunaan lahan di sempadan Batang Arau tahun 2005 dan tahun 2015 diperoleh hasil perubahan penggunaan lahan di sempadan Batang Arau. Untuk lebih jelasnya hasil perubahan penggunaan lahan di sempadan Batang Arau pada tahun 2005 dan tahun 2015 dapat dilihat pada tabel 3 berikut ini. 
Tabel 3. Luas Penggunaan Lahan Tahun 2005 dan Tahun 2015

\begin{tabular}{ccccccc}
\hline No. & $\begin{array}{c}\text { Penggunaan } \\
\text { Lahan }\end{array}$ & $\begin{array}{c}\text { Luas Penggunaan } \\
\text { Lahan (Ha) }\end{array}$ & $\begin{array}{c}\text { Peru- } \\
\text { bahan } \\
(\mathrm{Ha})\end{array}$ & $\begin{array}{c}\text { Persen- } \\
\text { tase } \\
(\%)\end{array}$ & Ket \\
\hline \multicolumn{1}{c}{ Th2005 } & Th2015 & & & \\
\hline 1 & Hutan & 15,266 & 20,428 & 10,104 & 3,44 & + \\
\hline 2 & $\begin{array}{c}\text { Kebun } \\
\text { Campuran }\end{array}$ & 100,409 & 130,096 & 17,072 & 22,60 & + \\
\hline 3 & Permukiman & 236,639 & 250,295 & 22,986 & 3,26 & + \\
\hline 4 & Sawah & 91,946 & 43,48 & 14,412 & 20,70 & - \\
\hline
\end{tabular}

Sumber: Analisis Citra Quicbird Tahun 2005 dan SPOT 6 Tahun 2015

Dari tabel 11 diatas dapat dilihat bahwa penggunaan lahan di sempadan Batang Arau selama periode 2005-2015 mengalami perubahan peningkatan dan penurunan luas setiap tahunnya yaitu: Perubahan penggunaan lahan di sempadan Batang Arau diataranya yaitu hutan mengalami peningkatan luas dari tahun 2005 hingga 2015 adalah sebesar 10,104 Ha dengan persentase perubahan luas $0,7 \%$, sawah mengalami penurunan luas sawah sekitar $-14,412$ Ha dengan persentase perubahan luas $-1,13 \%$, pemukiman mengalami peningkatan luas dari tahun 2005 sampai tahun 2015 sebesar 22,986 Ha dengan persentase perubahan luas 3,09\%, kebun campuran mengalami peningkatan luas dari tahun 2005 sampai tahun 2015 sekitar 17,072 Ha dengan persentase perubahan luas $4,65 \%$.

Hal ini senada dengan pola perubahan penggunaan lahan menurut Bintarto (1977) dalam Yani (2009). Pola perubahan penggunaan lahan di sempadan Batang Arau memanjang mengikuti aliran sungai dan memanjang mengikuti jalan.

Untuk melihat perubahan penggunaan lahan di sempadan Batang Arau tahun 2005 dan 2015 hasil analisis perubahan penggunaan lahan di sajikan lebih jelasnya pada pada gambar 3 berikut ini:

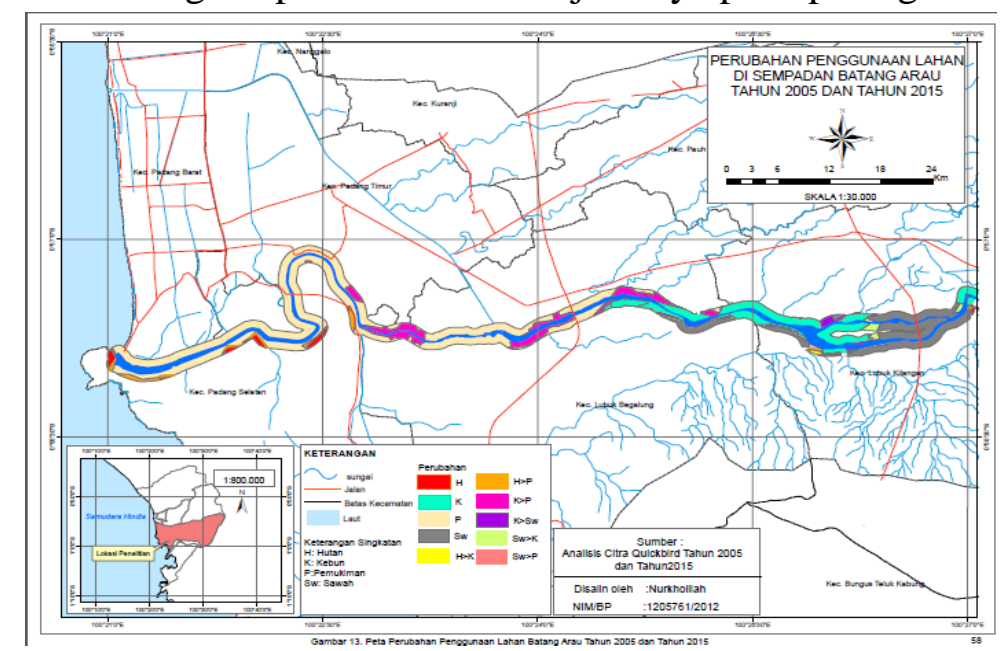

Gambar 3. Peta Perubahan Lahan di Sempadan Batang Arau Tahun 2005 dan Tahun 2015 


\section{PENUTUP}

\section{Kesimpulan}

Berdasarkan penelitian yang

sudah dilakukan pada sempadan Batang

Arau Kota Padang, maka dapat ditarik

kesimpulan sebagai berikut:

1. Penggunaan lahan tahun 2005 adalah pemukiman mencakup 236,639 Ha. Kebun campuran mencakup 100,409 Ha dengan persentase $22,60 \%$, sawah mencakup 91,946 $\mathrm{Ha}$ dengan persentase $20,70 \%$ dan hutan yaitu 15,266 Ha dengan persentase 3,44\%. Sedangkan penggunaan lahan tahun 2015 yang dominan masih sama dengan penggunaan lahan tahun 2005 yaitu pemukiman mencakup 250,295 Ha dengan persentase $54,94 \%$. Luas lahan kebun campuran berkurang yaitu 130,096 Ha dengan persentase $26,09 \%$, luas lahan sawah berkurang sekitar 43,48 Ha dengan persentase $14,46 \%$ dan luas lahan hutan bertambah yaitu sekitar 20,428 Ha dengan persentase $4,51 \%$.

2. Perubahan penggunaan lahan Hutan mengalami penambahan luas dari tahun 2005 hingga 2015 adalah sebesar 10,104 Ha dengan persentase perubahan luas $0,7 \%$. Sawah mengalami pengurangan luas sawah sekitar $-14,412$ Ha dengan persentase perubahan luas $-1,13 \%$. Pemukiman mengalami penambahan luas dari tahun 2005 sampai tahun 2015 sebesar 22,986 Ha dengan persentase perubahan luas 3,09\%. Kebun campuran mengalami penambahan luas dari tahun 2005 sampai tahun
2015 sekitar 17,072 Ha dengan persentase perubahan luas 4,65\%. Perubahan penggunaan lahan terbesar yaitu kebun campuran kearah penambahan luas areal sebesar $4,65 \%$.

\section{Saran}

Adapun saran yang dapat diberikan mengenai hasil dari penelitian dan pembahasan adalah:

1. Penggunaan lahan di sempada Batang Arau seperti pemukiman terus bertambah pesat setiap tahunnya, hal ini akan menyebabkan tumbuhan di sempadan sungai telah berubah menjadi pemukiman, sehingga sempadan Batang Arau sangat perlu mendapatkan perhatian khusus dan tindakan lebih lanjut, hal ini karena wilayah sempadan merupakan fungsi kawasan sebagai kawasan lindung yang perlu dilindungi fungsinya.

2. Hutan di sempadan Batang Arau Kota Padang mengalami perubahan setiap tahunnya, hal ini dapat menyebabkan longsor pada kawasan tersebut, sehingga perlu di sampaikan kepada masyarakat untuk lebih memperhatikan aktifitas yang dapat merusak fungsi hutan, agar dampak negatif terhadap sempadan dapat dikendalikan.

3. Pemerintah diharapkan perlu melalukan sosialisasi dengan masyarakat tentang pentingnya partisipasi masyarakat secara aktif dalam pengelolaan, pemnafaatan dan pengendalian daerah sempadan sungai. 


\section{DAFTAR RUJUKAN}

Arikunto, suharsimi.2010. Prosedur Penelitian. Jakarta: Rineka Cipta.

Badan Pusat Statistik Kota Padang. 2014. Padang Dalam Angka Tahun 2012. BPS Kota Padang. Padang.

Bapedalda 2010 Tentang Lahan Kritis Kota Padang.

Peraturan Menteri Pekerjaan Umum No. 28 Tahun 2015 Tentang Garis Sempadan Sungai.

Pratama, Faqih. 2010.' Analisis Perubahan Penggunaan Lahan Di Kecamatan Tegalrejo Kota Yogyakarta'.skripsi.Surakarta: Fakultas Geografi Universitas Muhammadiyah Surakarta.

Sutanto.1992. Penginderaan Jauh Jilid 1. Yogyakarta : Fakultas Geografi Universitas Gadjah Mada.

UU No 41 Tahun 1999 tentang kehutanan

Undang-Undang Republik Indonesia, Peraturan Menteri Pekerjaan Umum/Per.Men.PU Nomor 63/PRT/1963 tentang Garis Sempadan Sungai, Daerah Manfaat Sungai, Daerah Penguasaan Sungai dan Bekas Sungai.

Undang-Undang Republik Indonesia, Peraturan Pemerintah Republik Indonesia Nomor 35 Tahun 1991 Tentang Sungai.

Wahyunto, M.Z. Abidin, A. Priyono, dan Sunaryo. 2001. "Studi Perubahan Penggunaan Lahan Di Sub DAS Citarik, Jawa Barat dan DAS Kaligarang, Jawa Tengah”. Prosiding Seminar Nasional Multifungsi Lahan Sawah. Balai Penelitian Tanah. Bogor

Widyaningsih, WI. 2008.'Pengaruh Perubahan Tata Guna Lahan Di Sub Das Keduang Ditinjau Dari Aspek Hidrologi'.Tesis. Surakarta: Program Pascasarjana Universitas Sebelas.

Yani, Ahmad 2016.'’Perubahan Penggunaan Lahan di Sepanjang Sempadan Sungai Batang Kuranji Di Kota Padang', Skripsi.Padang: Fakultas Ilmu Sosial Universitas Negeri Padang. 